\title{
Microbial control of diatom bloom dynamics in the open ocean
}

\author{
Philip W. Boyd, ${ }^{1,2}$ Robert Strzepek, ${ }^{3}$ Steve Chiswell, ${ }^{2}$ Hoe Chang, ${ }^{2}$ Jennifer M. DeBruyn, ${ }^{4}$
} Michael Ellwood, ${ }^{5}$ Sean Keenan, ${ }^{2,6}$ Andrew L. King, ${ }^{7,8}$ Elisabeth W. Maas, ${ }^{2}$ Scott Nodder, ${ }^{2}$ Sylvia G. Sander, ${ }^{3}$ Philip Sutton, ${ }^{2}$ Benjamin S. Twining, ${ }^{9}$ Steven W. Wilhelm, ${ }^{10}$ and David A. Hutchins ${ }^{7}$

Received 2 August 2012; accepted 6 August 2012; published 19 September 2012.

[1] Diatom blooms play a central role in supporting foodwebs and sequestering biogenic carbon to depth. Oceanic conditions set bloom initiation, whereas both environmental and ecological factors determine bloom magnitude and longevity. Our study reveals another fundamental determinant of bloom dynamics. A diatom spring bloom in offshore New Zealand waters was likely terminated by iron limitation, even though diatoms consumed $<1 / 3$ of the mixed-layer dissolved iron inventory. Thus, bloom duration and magnitude were primarily set by competition for dissolved iron between microbes and small phytoplankton versus diatoms. Significantly, such a microbial mode of control probably relies both upon out-competing diatoms for iron (i.e., $K$-strategy), and having high iron requirements (i.e., $r$-strategy). Such resource competition for iron has implications for carbon biogeochemistry, as, blooming diatoms fixed three-fold more carbon per unit iron than resident non-blooming microbes. Microbial sequestration of iron has major ramifications for determining the biogeochemical imprint of oceanic diatom blooms. Citation: Boyd, P. W., et al. (2012), Microbial control of diatom bloom dynamics in the open ocean, Geophys. Res. Lett., 39, L18601, doi:10.1029/2012GL053448.

\section{Introduction}

[2] Diatoms are important bloom-forming phytoplankton that contribute $\sim 40 \%$ of global ocean productivity [Falkowski et al., 1998] and represent a major vector of

\footnotetext{
${ }^{1}$ NIWA Centre for Chemical and Physical Oceanography, Department of Chemistry, University of Otago, Dunedin, New Zealand.

${ }^{2}$ National Institute of Water and Atmosphere, Wellington, New Zealand.

${ }^{3}$ Department of Chemistry, University of Otago, Dunedin, New Zealand.

${ }^{4}$ Department of Biosystems Engineering and Soil Science, University of Tennessee, Knoxville, Tennessee, USA.

${ }^{5}$ Research School of Earth Sciences, Australian National University, Canberra, ACT, Australia.

${ }^{6}$ Division of Ocean Sciences, National Science Foundation, Arlington, Virginia, USA.

${ }^{7}$ Department of Biological Sciences, University of Southern California, Los Angeles, California, USA.

${ }^{8}$ Northeast Fisheries Science Center, NOAA, Milford, Connecticut, USA.

${ }^{9}$ Bigelow Laboratory for Ocean Sciences, East Boothbay, Maine, USA.

${ }^{10}$ Department of Microbiology, University of Tennessee, Knoxville, Tennessee, USA.
}

Corresponding author: P. W. Boyd, NIWA Centre for Chemical and Physical Oceanography, Department of Chemistry, University of Otago, Cumberland Street, Dunedin 9012, New Zealand.

C2012. American Geophysical Union. All Rights Reserved. 0094-8276/12/2012GL053448 carbon sequestration via downward particle export [Blain et al., 2007]. Diatom blooms have a duration of weeks and their initiation is driven by incident irradiance, nutrient availability and surface mixed-layer shallowing [Platt et al., 2009; Yamada and Ishizaka, 2006]. Our understanding of the controls on bloom magnitude and longevity centres on the interplay of mixed-layer-depth, nutrient inventory and grazing pressure [Cushing, 1990; Reynolds, 2006]. Recent research on diatom bloom dynamics has modelled their regulation by focusing on environmental factors including nutricline [Cermeno et al., 2008] or pycnocline [Behrenfeld, 2010] depth. However, biogeochemical models have largely overlooked the role of trace metals in controlling bloom dynamics, even though they are equally as influential as macronutrients in controlling phytoplankton processes [Boyd et al., 2007].

[3] In this study - FeCycle II, a GEOTRACES [www. geotraces.org] process study, we conducted a quasiLagrangian investigation of the influence exerted by iron (Fe) biogeochemistry on a spring diatom bloom. We directly measured temporal changes in the pre-existing dissolved $\mathrm{Fe}$ inventory, made concurrent estimates of biological Fe uptake and Net Primary Production (NPP), and followed the fate and biological recycling of this biogenic Fe. Our findings provide critical insights into how the contrasting Fe demands of diatom bloom-formers and the non-blooming microbial community, in conjunction with the fate of this biogenic Fe, control bloom dynamics and hence the magnitude of NPP.

\section{Bloom Initial Conditions, Development and Decline}

[4] FeCycle II was centred in a counter-clockwise eddy $\left(39^{\circ} 20^{\prime} \mathrm{S} 178^{\circ} 40^{\prime} \mathrm{W}\right)$ in subtropical waters east of New Zealand (Figure 1a), a region where an annually-recurring bloom is evident from satellite observations [Murphy et al., 2001]. After surveying this feature, a drogued drifter was deployed at the eddy centre on 17 September 2008 (year day 261) (Figure 1b). From day 262 until 272 the drifter tracked the eddy centre and provided the quasi-Lagrangian sampling platform needed to interpret temporal biogeochemical observations [Boyd et al., 2007] - but on day 273 it exited the centre (Figure 1b) due to $>15 \mathrm{~m} \mathrm{~s}^{-1}$ winds. Between days 262-272, FeCycle II captured the bloom evolution and initial decline (Figures 1c and 1d), and provides a 12 day comparison of the interplay between resource competition, Fe biogeochemistry, bloom dynamics, and productivity.

[5] The eddy centre (Figure 1b) was initially characterised by a $\sim 60 \mathrm{~m}$ mixed-layer (Figure $1 \mathrm{c}$ and Table $\mathrm{S} 1$ in the auxiliary material), a $63 \mathrm{~m}$ deep euphotic zone, and 

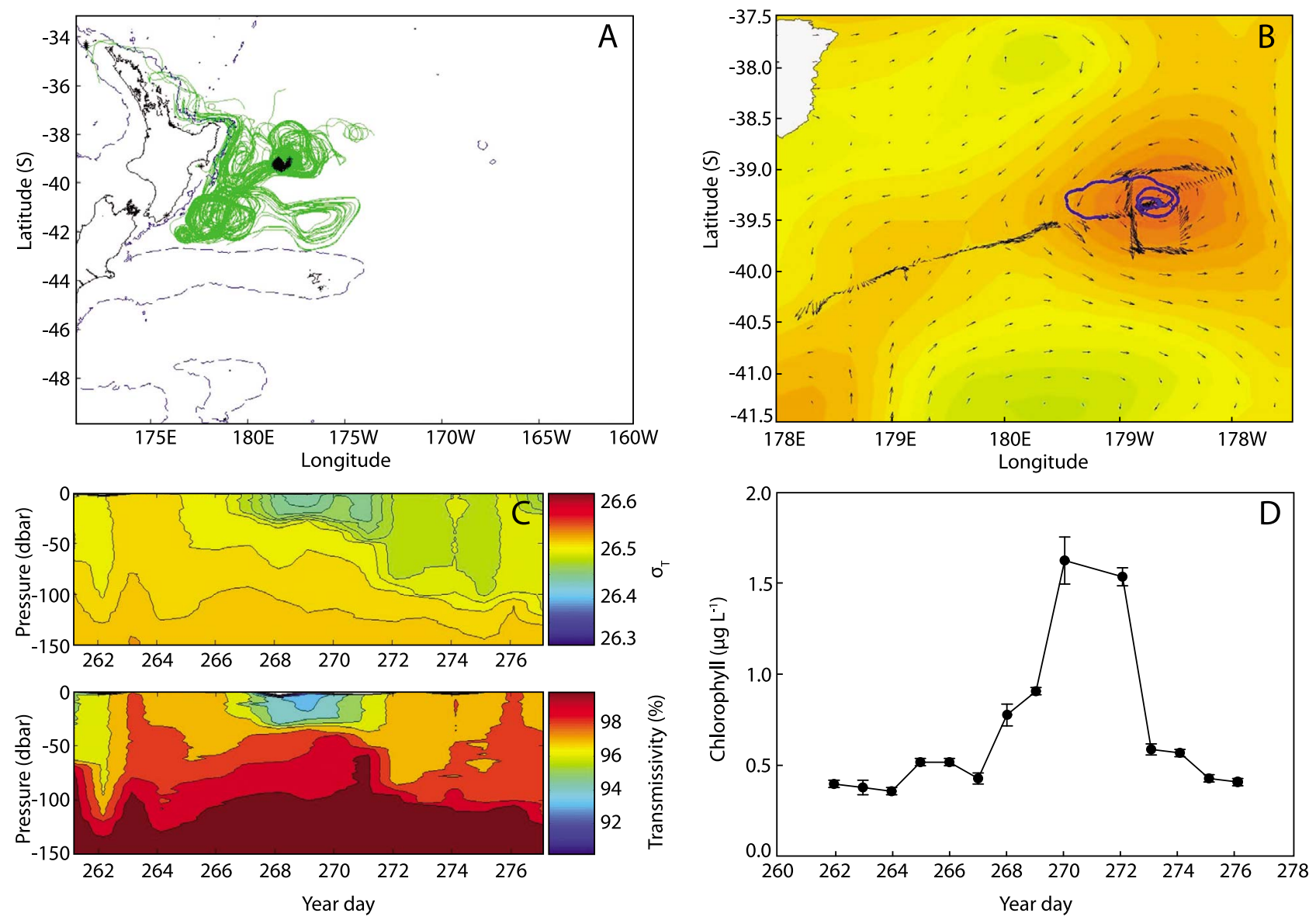

Figure 1. (a) FeCycle II eddy east of New Zealand (black shading). Green lines represent the predicted NW-SE trajectory of waters over the continental shelf (dashed lines) during eddy formation in early 2008 (see Animation S1 in the auxiliary material). (b) Initial location of a drogued drifter in the eddy centre and it's counterclockwise trajectory (blue line) overlaid on the vessel's underway acoustically-derived upper-ocean current flows (from 40.5S 178.3E eastwards to the eddy; closely-spaced black arrows, 5-25 $\mathrm{cm} \mathrm{s}^{-1}$ ). Both are superimposed on a regional altimetry simulation (widely-spaced arrows, $5-25 \mathrm{~cm} \mathrm{~s}^{-1}$ ) for September 2008 (auxiliary material). Two distinct phases are evident, days 261-272 in the eddy centre, then wind-driven expulsion. (c) Time-series of daily (pre-dawn) one metre vertically-resolved (top) density $(\sigma \mathrm{t})$ and (bottom) transmissivity $(\%)$ profiles $\sim 1 \mathrm{~km}$ from the drifter at the eddy centre. Initial variability in mixed-layer depth was followed by mixed-layer shallowing then abrupt deepening after day 272 . Decreasing transmissivity was due to the accumulation of phytoplankton biomass that peaked on days 269/270. (d) Time-series of satellite ocean colourderived chlorophyll concentration in the waters surrounding the eddy centre (i.e., $\sim 150 \mathrm{~km}^{2}$ ), bars denote variability around the mean of the central and 8 surrounding $4 \mathrm{~km}$ pixels.

chlorophyll (Chl) of $0.41 \pm 0.02 \mu \mathrm{g} \mathrm{L}^{-1}$ across a $\sim 150 \mathrm{~km}^{2}$ area (Figure 1d). ${ }^{1}$ At this time nitrate, phosphate and silicate were $4.1 \pm 0.2,0.5 \pm 0.05$ and $2.1 \pm 0.1 \mu \mathrm{mol} \mathrm{L^{-1 }}$, respectively. Dissolved Fe was $0.60 \pm 0.07 \mathrm{nmol} \mathrm{L}^{-1}$, giving an initial mixed-layer inventory of $\sim 38 \mu \mathrm{mol} \mathrm{m}^{-2}$ (Figure 2, top) maintained in solution by high-affinity Fe-binding ligands $\left(1.4 \pm 0.1 \mathrm{nmol} \mathrm{L}^{-1}\right)$. Mixed-layer particulate $\mathrm{Fe}$ stocks were also high $\left(>200 \mu \mathrm{mol} \mathrm{m}^{-2}\right)$, and thus additional dissolved $\mathrm{Fe}$ was very likely supplied by photochemical breakdown of particulate Fe [Johnson et al., 1994; Borer et al., 2005] (Figure S1). The probable source of this Fe was from lateral advection of resuspended shelf-sediments during eddy formation (S. Animation). This nearshore provenance is supported by the ratio of upper ocean particulate $\mathrm{Fe}$ to manganese during FeCycle II (data not shown) which

${ }^{1}$ Auxiliary materials are available in the HTML. doi:10.1029/ 2012GL053448. was comparable to that from NW Pacific sites where lateral sediment-derived Fe was evident [Lam and Bishop, 2008].

[6] The bloom evolved as the mixed layer shallowed (Figure 1c), peaking at $1.6 \pm 0.1 \mu \mathrm{g} \mathrm{Chl} \mathrm{L}^{-1}(92.4 \%$ transmissivity) on day 269 before declining rapidly (Figures 1c and S2). It is difficult to pinpoint the onset of the diatom bloom as seed stocks, for example of Leptocylindrus sp. (Figure S2) where present at low abundances early in FeCycle II, and increased tenfold within six days as the bloom evolved and consumed silicate, a trend evident in many mesoscale iron-enriched diatom blooms [Boyd et al., 2007]. There are also issues with the interpretation of temporal trends in the dissolved $\mathrm{Fe}$ inventory (Figure 2, top) as it was altered concurrently by changes in mixed-layer depth, biological Fe uptake, and putative Fe supply via photochemical degradation of particulate Fe. Nevertheless, by day 268 , prior to the phytoplankton biomass peak and when $<50 \%$ of the mixed-layer nutrient inventories had been 



Fig. 2

Year day

Figure 2. (top) Column-integrated mixed-layer dissolved $\mathrm{Fe}$ (see Table S1 for mixed layer depth), and photosynthetic competence $\left(\mathrm{F}_{\mathrm{v}} / \mathrm{F}_{\mathrm{m}}\right.$, dimensionless $)$ of the phytoplankton community sampled for incubations presented in Figure 2 (middle). (middle) Size-partitioned biological Fe uptake. (bottom) The initial dissolved Fe inventory (on day 262 from Figure 2 (top), adjusted for a $24 \mathrm{~h} \mathrm{lag}$ ) minus daily community $\mathrm{Fe}$ uptake (black line and symbols), and of diatoms alone (red line and symbols) (data from Figure 2, middle). The horizontal dashed line denotes that stocks would be fully depleted by day 287 if the community used only new Fe. Inventories and fluxes were integrated to the base of the surface-mixed-layer using daily estimates from Table S1. Note, time-series data in Figure 2 (middle) cannot be directly compared with most other datasets in Figures 1-4, as the $24 \mathrm{~h}$ incubations introduce a 1 day lag. See main text for caveats about the influence of mixed-layer shoaling and photochemical degradation of particulate iron on dissolved iron inventories.

consumed (i.e., $\sim 2.4 \pm 0.2$ (nitrate), $0.27 \pm 0.03$ (phosphate) and $1.2 \pm 0.1$ (silicate) $\left.\mu \mathrm{mol} \mathrm{L}{ }^{-1}\right)>90 \%$ of the dissolved Fe inventory had been taken up (Figure 2, top).

[7] Why did the diatom bloom decline after day 269 ? (Figures 1c and S2). Herbivory can be ruled out as shipboard prey-labelling experiments revealed that copepods consumed $<15 \%$ of daily NPP fixed by $>20 \mu$ m phytoplankton (Table S2). It is unlikely that silicate limitation triggered bloom decline, as open-ocean diatom blooms can draw silicate down to $\sim 0.3 \mu \mathrm{mol} \mathrm{L}^{-1}$ [Allen et al., 2005] and we did not observe $<1 \mu \mathrm{mol} \mathrm{Si} \mathrm{L}^{-1}$ during our study. By day 268 , mixed-layer Fe was $<0.1 \mathrm{nmol} \mathrm{Fe} \mathrm{L}^{-1}$ (Table S1) a concentration which limits NPP [Boyd and Abraham, 2001], and which resulted in a small but significant decrease in photosynthetic competence $\left(\mathrm{F}_{\mathrm{v}} / \mathrm{F}_{\mathrm{m}}\right)$ (Figure 2, top). Together, these observations point to Fe limitation as the mostly likely cause of the bloom decline.

\section{Patterns in Biological Uptake of New and Recycled Iron}

[8] The bloom was comprised of large diatoms ( $>20 \mu \mathrm{m})$, in particular Asterionellopsis glacialis $\left(56 \mathrm{~mm}^{3}\right)$ and Leptocylindrus sp. $\left(588 \mu \mathrm{m}^{3}\right)$ (Figure S2). It is highly unlikely that the diatoms drove the bloom into Fe limitation, as they were responsible for $<1 / 3$ of community Fe uptake (Figure 2, middle and 2, bottom). In contrast, the $<2 \mu \mathrm{m}$ autotrophic (mainly Synechococcus), and heterotrophic bacteria had the highest $\mathrm{Fe}$ uptake rates (Figure 2, middle), and despite exhibiting no sustained increase in abundance (Figures S2 and S3) or cell size (data not shown) cells $<20 \mu \mathrm{m}$ took up $\sim 70 \%$ of the dissolved $\mathrm{Fe}$ inventory (Figure 2, middle). Rates of community Fe uptake were greatest between days 262 and 266 when phytoplankton stocks were relatively low. After day 266, the main phase of bloom development (Figure 1c) Fe uptake rates decreased (Figure 2, middle), probably due to both mixed-layer shallowing (Figure 1c) and a shift from luxury iron uptake (defined as luxurious uptake and storage of iron at high dissolved iron concentrations [Buitenhuis and Geider, 2010; Marchetti et al., 2009] to lower rates. Although non-biological processes also altered the mixed-layer iron inventory, cumulative iron uptake was sufficient to account for the removal of stocks of new Fe, and thus cells probably became increasingly reliant upon recycled Fe (Figure 2, bottom).

[9] Additional microbial controls on $\mathrm{Fe}$ availability (such as chemical speciation) to blooming diatoms emerge when the fate of biogenic Fe is examined. Pico- and nanoplanktonic Fe was rapidly turned over within a pelagic recycling loop via high rates of viral lysis, microzooplankton bacterivory and herbivory (Figure 3, left). In contrast, diatom Fe was recycled primarily by mesozooplankton, and diatoms were conspicuous within faecal pellets (Figure S4). Rates of $\mathrm{Fe}$ recycling were comparable to those for $\mathrm{Fe}$ uptake (Figure 2, middle; cf. Figure 3, left). Despite sustained daily recycling of significant amounts of Fe, relative to the diatoms' initial $\mathrm{Fe}$ uptake rates, the bloom declined rapidly after day 269.

[10] Biogenic Fe recycled in the mixed-layer is potentially available to all biota [Boyd et al., 2007; Strzepek et al., 2005]. However, after day 266 when Fe was primarily supplied to the biota by recycling (Figure 2, bottom), $\sim 70 \%$ of Fe uptake was by pico- and nano-plankton (Figure 2, middle). Thus, despite diatoms requiring little Fe to bloom (Figure 2, bottom) [Strzepek et al., 2011; this study], they could not access enough recycled $\mathrm{Fe}$ to exploit the available macronutrients (i.e., $\sim 2.2 \pm 0.2(\mathrm{~N}), 0.25 \pm 0.02(\mathrm{P})$ and $1.1 \pm$ 0.1 (Si) $\mu \mathrm{mol} \mathrm{L}^{-1}$ after day 268 ) and continue blooming. 

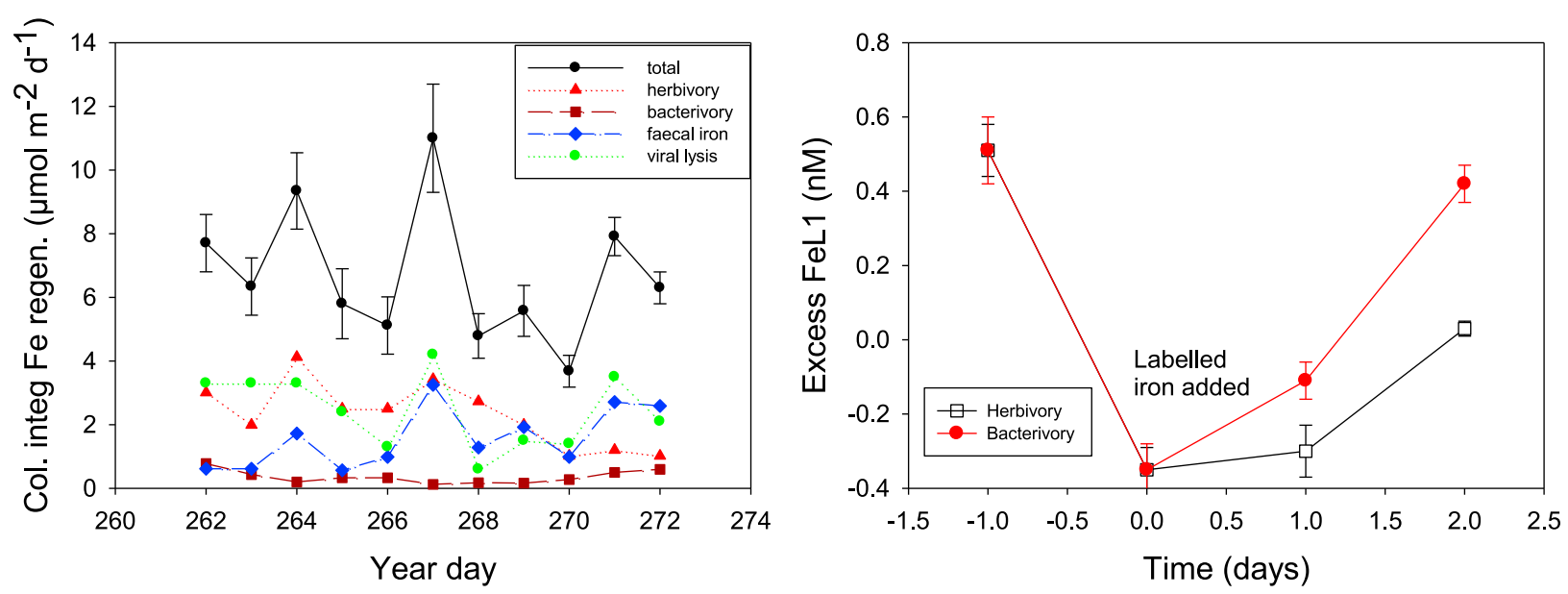

Figure 3. (left) Biological Fe recycling by four distinct mechanisms. (right) Time-series of high-affinity Fe-binding ligand concentrations during one of the Fe radiotracer experiments to measure microzooplankton bacterivory and herbivory of nanophytoplankton. (i.e., day 266 presented in Figure 3 left), expressed as excess of ligand concentration relative to dissolved Fe. The radiotracer $\mathrm{Fe}$ was added at time-zero. For methods see auxiliary material. Note, early in FeCycle II the magnitude of the decrease in the new Fe inventory and the estimated Fe resupplied from recycling exceeds the measured Fe uptake by $\sim$ twofold.

Their inability to utilize this Fe may be due to the superior ability of the smaller cells to rapidly acquire $\mathrm{Fe}$ due to physico-chemical advantages - e.g., higher surface-area: volume ratio, faster diffusion rates [Beardall et al., 2009; Irwin et al., 2006] and active transport systems [Butler, 1998] - and/or the limited bioavailability of forms of $\mathrm{Fe}$ released during recycling (Strzepek et al. [2005] but cf. Sato et al. [2007]). Although diatom culture studies favour the former 'kinetics' scenario [Strzepek et al., 2011], we measured enhanced production/release of high-affinity Fe-binding ligands during a grazing experiment (Figure 3), which may alter Fe bioavailability to diatoms.

\section{Discussion}

[11] There are major ecological ramifications resulting from microbes and small phytoplankton dominating the competition for this limited resource throughout rapidly changing Fe biogeochemical conditions (Figures 2, bottom and 3 , left). Firstly, these small cells consumed $\sim 70 \%$ of the new Fe inventory, and such microbial sequestration of new $\mathrm{Fe}$ exerts a major influence on the Fe-requiring diatoms. Secondly, microbes dominate Fe uptake in the latter stages of FeCycle II suggesting that they also outcompete diatoms for recycled Fe. Thus, uptake of new Fe by microbes and its subsequent entrainment in a recycled $\mathrm{Fe}$ loop may place limits on diatoms accessing $\mathrm{Fe}$ and hence on bloom magnitude and longevity.

[12] Resource competition theory in aquatic environments has defined two strategies: $r$ (i.e., opportunists that efficiently exploit new sources of resources) versus $K$ (i.e., a high nutrient affinity and low resource requirements) [Arrigo, 2005; Edwards et al., 2011]. Applying such conventions to the FeCycle II assemblage, the blooming diatoms would be viewed as $r$ and the non-blooming microbes as $K$ strategists. Yet, in terms of the competition for Fe, microbes appeared to have both a high affinity ( $K$ strategy) and high resource acquisition capabilities ( $r$ strategy), as they consumed most of the Fe inventory, without any significant increase in their stocks. Unlike other nutrients such as nitrate or phosphate [Arrigo, 2005], pico- and nanoplankton appear to be equally adept at accessing either new (Figure 2, top) or regenerated Fe (Figure 3, left). Studies to date have considered whether there are specific microbial physiological functional traits for nutrient acquisition [Edwards et al., 2011] but have not investigated this issue for trace metals. Evidence of both $K$ and $r$ strategies by microbes during FeCycle II may point to microbial consumption of this scarce resource, when sufficiently available, at higher than required rates (so-called luxury uptake) [Buitenhuis and Geider, 2010].

[13] How does microbial control of diatom bloom dynamics alter its biogeochemical imprint? Firstly, as diatoms fix significantly more $\mathrm{C}$ per unit $\mathrm{Fe}$ than microbes and small phytoplankton (Figure 4), much less of the pre-bloom Fe inventory ( $\sim 30 \%$, Figure 4 , bottom) can be leveraged to draw down dissolved inorganic carbon or nitrate. Both have implications for bloom productivity, and potentially for the magnitude of downward carbon sequestration. Secondly, although most of the pre-bloom Fe inventory is retained in surface waters via rapid microbial recycling, much of this inventory may be unavailable to diatoms due to it being bound to strong ligands, and/or due to diatoms' low affinity for recycled $\mathrm{Fe}$ relative to smaller cells. Such unavailability contradicts the findings of recent modelling experiments on mesoscale Fe-enrichment and diatom blooms. The models indicate a high sensitivity of projected Fe-mediated carbon sequestration to the magnitude of pelagic $\mathrm{Fe}$ recycling [Gnanadesikan et al., 2003; Sarmiento et al., 2010].

[14] The inability of diatoms to out-compete smaller cells for new $\mathrm{Fe}$, and/or access sufficient recycled $\mathrm{Fe}$, means that they probably require higher ambient dissolved $\mathrm{Fe}$ concentrations in order to bloom - i.e., a resource threshold may exist - despite diatoms employing a competitive strategy of relatively low intracellular $\mathrm{Fe}$ demand. Thus, the magnitude of the spring bloom, in the study area and other regions such 

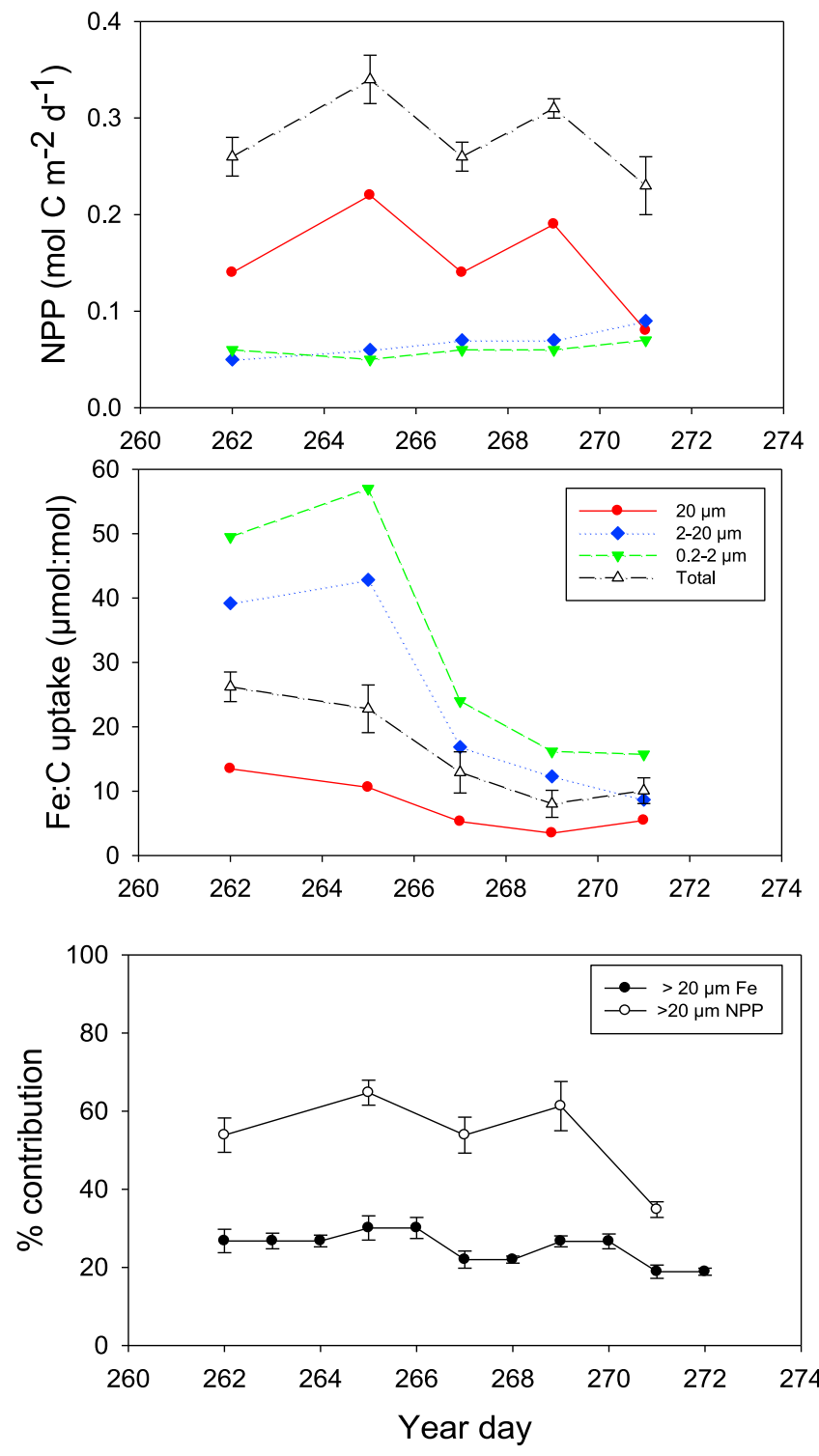

Figure 4. (top) Size-partitioned Net Primary Production (NPP). (middle) Time-series of the molar ratios of columnintegrated Fe uptake and NPP for microbes, small phytoplankton, diatoms and the community. (bottom) Percentage contribution of diatoms to community NPP and Fe uptake. Note, based on daily noontime vertical profiles, the depth of the euphotic zone was comparable to that of the surface mixed-layer, since as the mixed layer shoaled and the bloom evolved, there was a concomitant increase in vertical light attenuation with increasing biomass.

as the Southern Ocean where diatoms dominate blooms, may be determined annually by the winter dissolved $\mathrm{Fe}$ inventory and how much it exceeds this putative resource threshold (Figure S5). Such a resource threshold is probably fixed, as microbial and small phytoplankton stocks are under tight grazer control [Price et al., 1994; Strzepek et al., 2005], and once maximum $\mathrm{Fe}$ uptake rates are attained, more $\mathrm{Fe}$ can only be consumed if they can increase their stocks significantly.

[15] To date, most ocean biogeochemistry and climate models have relied solely upon phytoplankton $\mathrm{Fe}: \mathrm{C}$ ratios from lab-cultures [Sunda and Huntsman, 1995] to set the relationship between $\mathrm{Fe}$ and $\mathrm{C}$ biogeochemistry and climate. FeCycle II reveals that diatom $\mathrm{Fe}$ requirements alone will not determine the bounds on bloom productivity, since the relative $\mathrm{Fe}$ requirements and $\mathrm{Fe}$ affinity of microbes and small phytoplankton within the co-occurring assemblage must also be considered. The constraints imposed on diatom bloom dynamics due to a microbial stranglehold on Fe biogeochemistry must be incorporated into models which examine the relationship between Fe supply, blooms and C sequestration [Gnanadesikan et al., 2003; Sarmiento et al., 2010; Tagliabue and Arrigo, 2006] before we can accurately predict the effects of past, present and future changes in Fe supply on the ocean $\mathrm{C}$ cycle.

[16] Acknowledgments. We thank the officers and crew of RV Tangaroa. We acknowledge expert technical support from NIWA Vessels and from NIWA staff. We are grateful for the constructive comments of two anonymous reviewers which helped improve this manuscript. This research was funded by grants from the New Zealand Ministry for Science and Innovation. BST, SWW and DAH were supported by a grant from the US National Science Foundation (OCE 0825379/0825405/0825319). ME was funded by Australian Research Council grants DP0770820 and DP110100108.

[17] The Editor thanks two anonymous reviewers for assisting in the evaluation of this paper.

\section{References}

Allen, J. T., et al. (2005), Diatom carbon export enhanced by silicate upwelling in the northeast Atlantic, Nature, 437, 728-732, doi:10.1038/ nature 03948 .

Arrigo, K. R. (2005), Marine microorganisms and global nutrient cycles, Nature, 437, 349-355, doi:10.1038/nature04159.

Beardall, J., et al. (2009), Allometry and stoichiometry of unicellular, colonial and multicellular phytoplankton, New Phytol., 181, 295-309, doi:10.1111/j.1469-8137.2008.02660.x.

Behrenfeld, M. J. (2010), Abandoning Sverdrup's Critical Depth Hypothesis on phytoplankton blooms, Ecology, 91,977-989, doi:10.1890/09-1207.1.

Blain, S., et al. (2007), Effect of natural iron fertilization on carbon sequestration in the Southern Ocean, Nature, 446, 1070-1074, doi:10.1038/ nature 05700

Borer, P. M., B. Sulzberger, P. Reichard, and S. M. Kraemer (2005), Effect of siderophores on the light-induced dissolution of colloidal iron(III) (hydr)oxides, Mar. Chem., 93, 179-193, doi:10.1016/j.marchem. 2004.08.006.

Boyd, P. W., and E. R. Abraham (2001), Iron-mediated changes in phytoplankton photosynthetic competence during SOIREE, Deep Sea Res., Part II, 48, 2529-2550, doi:10.1016/S0967-0645(01)00007-8.

Boyd, P. W., et al. (2007), A synthesis of mesoscale iron-enrichment experiments 1993-2005: Key findings and implications for ocean biogeochemistry, Science, 315, 612-617, doi:10.1126/science.1131669.

Buitenhuis, E. T., and R. J. Geider (2010), A model of phytoplankton acclimation to iron-light colimitation, Limnol. Oceanogr., 55, 714-724, doi:10.4319/lo.2009.55.2.0714.

Butler, A. (1998), Acquisition and utilization of transition metal ions by marine organisms, Science, 281, 207-209, doi:10.1126/science. 281.5374. 207.

Cermeno, P., et al. (2008), The role of nutricline depth in regulating the ocean carbon cycle, Proc. Natl. Acad. Sci. U. S. A., 105, 20,344-20,349, doi:10.1073/pnas.0811302106.

Cushing, D. H. (1990), Plankton production and year-class strength in fish populations: An update of the match/mismatch hypothesis, Adv. Mar. Biol., 26, 249-293, doi:10.1016/S0065-2881(08)60202-3.

Edwards, K. E., C. A. Klausmeier, and E. Litchman (2011), Evidence for a three-way tradeoff between nitrogen and phosphorus competitive abilities and cell size in phytoplankton, Ecology, 92, 2085-2095, doi:10.1890/11-0395.1.

Falkowski, P. G., R. T. Barber, and V. Smetacek (1998), Biogeochemical controls and feedbacks on ocean primary production, Science, 281, 200-206, doi:10.1126/science.281.5374.200.

Gnanadesikan, A., R. D. Slater, and J. L. Sarmiento (2003), Effects of patchy ocean fertilization on atmospheric carbon dioxide and biological production, Global Biogeochem. Cycles, 17(2), 1050, doi:10.1029/ 2002 GB001940. 
Irwin, A. J., Z. V. Finkel, O. M. E. Schofield, and P. G. Falkowski (2006), Scaling-up from nutrient physiology to the size-structure of phytoplankton communities, J. Plankton Res., 28, 459-471, doi:10.1093/plankt/fbi148.

Johnson, K. S., K. H. Coale, V. A. Elrod, and N. W. Tindale (1994), Iron photochemistry in seawater from the equatorial Pacific, Mar. Chem., 46, 319-334, doi:10.1016/0304-4203(94)90029-9.

Lam, P. J., and J. K. B. Bishop (2008), The continental margin is a key source of iron to the HNLC North Pacific Ocean, Geophys. Res. Lett., 35, L07608, doi:10.1029/2008GL033294.

Marchetti, A., et al. (2009), Ferritin is used for iron storage by bloomforming marine pennate diatoms, Nature, 457, 467-470, doi:10.1038/ nature07539.

Murphy, R. J., et al. (2001), Phytoplankton distributions around New Zealand derived from SeaWiFS remotely-sensed ocean colour data, N. Z. J. Mar. Freshw. Res., 35, 343-362, doi:10.1080/00288330.2001.9517005.

Platt, T., et al. (2009), The phenology of phytoplankton blooms: Ecosystem indicators from remote sensing, Ecol. Modell., 220, 3057-3069, doi:10.1016/j.ecolmodel.2008.11.022.

Price, N. M., B. A. Ahner, and F. M. M. Morel (1994), The equatorial Pacific Ocean: Grazer-controlled phytoplankton populations in an ironlimited ecosystem, Limnol. Oceanogr., 39, 520-534, doi:10.4319/ lo.1994.39.3.0520.

Reynolds, C. S. (2006), The Ecology of Phytoplankton, 550 pp., Cambridge Univ. Press, Cambridge, U. K., doi:10.1017/CBO9780511542145.

Sarmiento, J. L., R. D. Slater, J. P. Dunne, A. Gnanadesikan, and M. R. Hiscock (2010), Efficiency of small scale carbon mitigation by patch iron fertilization, Biogeosciences, 7, 3593-3624, doi:10.5194/bg-7-35932010.

Sato, M., S. Takeda, and K. Furuya (2007), Iron regeneration and organic iron(III)-binding ligand production during in situ zooplankton grazing experiment, Mar. Chem., 106, 471-488, doi:10.1016/j.marchem. 2007.05.001.

Strzepek, R. F., M. T. Maldonado, J. L. Higgins, J. Hall, K. Safi, S. W. Wilhelm, and P. W. Boyd (2005), Spinning the "Ferrous Wheel": The importance of the microbial community in an iron budget during the FeCycle experiment, Global Biogeochem. Cycles, 19, GB4S26, doi:10.1029/2005GB002490.

Strzepek, R. F., et al. (2011), Adaptive strategies by Southern Ocean phytoplankton to lessen iron limitation: Uptake of organically-complexed iron and reduced cellular iron requirements, Limnol. Oceanogr., 56, 1983-2002, doi:10.4319/1o.2011.56.6.1983.

Sunda, W. G., and S. A. Huntsman (1995), Iron uptake and growth limitation in oceanic and coastal phytoplankton, Mar. Chem., 50, 189-206, doi:10.1016/0304-4203(95)00035-P

Tagliabue, A., and K. R. Arrigo (2006), Processes governing the supply of iron to phytoplankton in stratified seas, J. Geophys. Res., 111, C06019, doi:10.1029/2005JC003363.

Yamada, K., and J. Ishizaka (2006), Estimation of interdecadal change of spring bloom timing, in the case of the Japan Sea, Geophys. Res. Lett., 33, L02608, doi:10.1029/2005GL024792. 